\title{
The Analysis of the Problem About Application-Oriented Talent Cultivation of Shandong Colleges in the View of Supply-Side Structural Reform
}

\author{
Mingming Wang \\ School of Shandong Xiehe University, Jinan, Shandong,China \\ 476398949@qq.com
}

Keywords: Shandong Colleges and Universities, Application-Oriented Talent Cultivation, Supply-Side Structural Reform

\begin{abstract}
The main purpose of this study is to determine the meaning of the supply side structural reform and applied talents, and to comb the existing problems of the training of Applied Talents in Shandong colleges and Universities under the view of the structural reform of the supply side. This paper uses literature, survey and comprehensive analysis to carry out research. Through the study of literature, the structural reform of the supply side mainly refers to the use of reform to promote structural adjustment and enhance the adaptability and flexibility of the supply structure to the demand structure; the meaning of applied talents mainly refers to the strong practical application ability, the comprehensive development of knowledge, ability and quality, the social adaptability and the sense of post service. People who directly meet the needs of economic and social development. Through the investigation and comprehensive analysis, the main problems of the training of Applied Talents in Shandong colleges and Universities under the view of the structural reform of the supply side are as follows: the matching degree of professional structure and industrial structure needs to be improved, and the matching degree of the quality of talent training in Colleges and Universities and the demand for industrial development needs to be promoted.
\end{abstract}

\section{Introduction}

Facing the new normal economic and social development in China, the Party Central Committee has fully deployed the "supply side structural reform" to promote the change and docking of the supply structure and demand, and radiate the strong vitality of the comprehensive reform (Chen Yongxian, 2017). There is a close correlation between the structural reform of the supply side and the training of Applied Talents in local colleges and universities. The reform of the economic supply side requires the training and supply of the corresponding applied professional technical talents. The supply side reform of higher education is based on the actual needs of the structural contradiction between supply and demand in Colleges and universities (Ceng Xiulan, 2016). The evolution of industrial pattern changes the demand for talent training, forcing local universities to turn from "demand pull" to "supply side promotion" (Duan Lihua, 2016), local undergraduate course. The supply side reform of talent training in Colleges and universities can continuously enhance the regional appropriateness of local undergraduate universities (Zhang Jinfu, 2017).

\section{Supply side structural reform and the meaning of applied talents}

The research on the structural reform of the supply side is more abundant. Some scholars have proposed that the structural reform of the supply side is to promote structural adjustment by means of reform, reduce the supply of invalid and low end, expand the supply of effective and middle and high end, and enhance the adaptability and flexibility of the supply structure to the demand structure (Peng Shouqing, 2016). With regard to the meaning of applied talents, scholars believe that applied talents emphasize practical application ability in terms of concept; in terms of characteristics, applied talents have been developed in an all-round way in knowledge, ability and quality. The ability is the practical application ability to discover, analyze and solve problems; from the society In terms of 
function and value, applied talents emphasize the "direct correspondence" with economic and social development, and emphasize social adaptation and post service awareness (Pan Maoyuan and so on, 2009; Li Youliang, 2014; Hou Changlin, etc., 2015). With regard to the training of applied talents, scholars believe that the practice teaching system should be built around the requirements of the coordinated development of the knowledge, ability and quality of applied talents, and the theory and practice should be made equal, and the ability training and quality education should be combined (Liu Huanyang, 2012; Wu Zhongjiang, and so on, 2014).

\section{Problems in the training of Applied Talents of Shandong universities from the perspective of supply side structural reform}

Through combing the present situation of the training of Applied Talents of Shandong University and combining with the forecast of applied talent demand under the background of industrial transformation and upgrading, this paper mainly analyzes the upgrading of industrial transformation from the aspects of the matching degree of professional structure and industrial structure, the quality of talent training and the matching degree of industrial development demand in the process of interaction between universities and industry development, and the matching degree of the quality of talents training in universities and the demand of industrial development. Under the background of Shandong universities, there are difficulties in talent training. The influence factors of the training of Applied Talents in Shandong colleges and universities are summed up from the aspects that are difficult to meet the needs of the economic and social development, the talent training mode is difficult to adapt to the requirements of the personnel training specifications, the cooperative education mechanism needs to be optimized, the teachers' structure needs to be rationalized, and the teaching quality guarantee system needs to be strengthened.

\subsection{The matching degree of professional structure and industrial structure needs to be improved}

This study starts with the subjects, and collects data by literature and interview. According to the principle of proximity, 12 private universities in Shandong were selected as samples to analyze their predicament and influencing factors in the process of training applied talents. After years of development, the private colleges and universities in Shandong have gradually optimized the layout of disciplines and specialties. According to the social needs, employment and their own running practice, they have constantly adjusted the subject setting. It has basically formed the main disciplines of science, engineering, management, medicine, literature and art, with both education, economics, agronomy and law and so on. The subject structure of the subject.

After the adjustment and upgrading of the regional industrial structure in Shandong, the major needed major, such as new industries, new technologies, new materials, new energy and other emerging industries, is not enough in Shandong's colleges and universities, and the training of corresponding professional talents is also scarce. There are only 1 marine and marine engineering majors in marine engineering. There are only 1 energy and power engineering majors in energy power. There are only 1 composite materials and engineering majors in materials majors. There are still gaps in the professional distribution of new industries and new technologies. There are gaps in modern agriculture, such as natural protection, environmental ecology, aquatic products and grass science. On the other hand, 9 colleges and universities, such as marketing, mechanical design and manufacture and automation, computer science and technology, engineering cost, have been set up in 9 colleges and universities. 
Table 1 a list of professional categories for undergraduate majors

of Shandong private university.

\begin{tabular}{|c|c|c|c|c|c|}
\hline disciplines & $\begin{array}{l}\text { Professional } \\
\text { category }\end{array}$ & disciplines & Professional category & disciplines & $\begin{array}{l}\text { Professional } \\
\text { category }\end{array}$ \\
\hline philosophy & Philosophy class & \multirow{5}{*}{ agronomy } & $\begin{array}{c}\text { Nature conservation } \\
\text { and environmental } \\
\text { ecology }\end{array}$ & art & Art theory \\
\hline economics & Finance class & & Animal production & \multirow{12}{*}{ engineering } & Mechanics class \\
\hline \multirow{4}{*}{ A law } & Class of law & & Animal medicine & & $\begin{array}{c}\text { Water conservancy } \\
\text { class }\end{array}$ \\
\hline & $\begin{array}{l}\text { A class of } \\
\text { ethnology }\end{array}$ & & Aquatic class & & $\begin{array}{l}\text { Surveying and } \\
\text { mapping class }\end{array}$ \\
\hline & Marxist theory & & Grass science class & & Geological class \\
\hline & $\begin{array}{c}\text { The public } \\
\text { security science }\end{array}$ & \multirow{6}{*}{ medical } & Basic medical science & & mining \\
\hline \multirow{9}{*}{$\begin{array}{l}\text { neo-confucia } \\
\text { nism }\end{array}$} & Physics class & & Oral medicine & & Armor class \\
\hline & Day's section & & $\begin{array}{c}\text { Public health and } \\
\text { preventive medicine }\end{array}$ & & $\begin{array}{c}\text { Nuclear } \\
\text { engineering class }\end{array}$ \\
\hline & geoscience & & In the medical & & $\begin{array}{l}\text { Agricultural } \\
\text { engineering }\end{array}$ \\
\hline & $\begin{array}{l}\text { Atmospheric } \\
\text { science }\end{array}$ & & $\begin{array}{c}\text { Integrated Chinese } \\
\text { and western medicine }\end{array}$ & & $\begin{array}{c}\text { Forestry } \\
\text { engineering }\end{array}$ \\
\hline & Marine science & & Forensic science class & & $\begin{array}{l}\text { Biomedical } \\
\text { engineering }\end{array}$ \\
\hline & geophysics & \multirow{4}{*}{$\begin{array}{c}\text { managemen } \\
\mathrm{t}\end{array}$} & $\begin{array}{l}\text { Agricultural } \\
\text { economic } \\
\text { management }\end{array}$ & & $\begin{array}{l}\text { Safety science and } \\
\text { engineering }\end{array}$ \\
\hline & Geology class & & Public administration & & $\begin{array}{l}\text { Public security } \\
\text { technology }\end{array}$ \\
\hline & Psychology class & & \multirow{2}{*}{$\begin{array}{c}\text { Book intelligence and } \\
\text { archive management }\end{array}$} & \multirow{2}{*}{ history } & \multirow{2}{*}{ History class } \\
\hline & Statistics class & & & & \\
\hline
\end{tabular}

Note: this table is organized by the ministry of education's undergraduate professional catalogue (2012) (hereinafter referred to as the catalogue).

Among the categories of the 12 disciplines divided by the catalogue, the specialties of Shandong private colleges and universities are only distributed in 10 disciplines, which are blank in the 2 
disciplines of philosophy and history. In 10 universities, the proportion of engineering majors is the highest, reaching $42.90 \%$, followed by management, and the proportion of 78 majors is $24.07 \%$; the number of literature, art and medicine is equivalent to 27,25 and 23 , respectively, $0.083 \%, 0.077 \%$ and $0.070 \%$, respectively, economics, education and education. The number of science and science majors were 13, 9 and 5 respectively, which accounted for $0.083 \%, 0.077 \%$ and $0.070 \%$, respectively. In the last place, science, law and agronomy were 5, 3 and 2, respectively, and the proportion was $0.015 \%, 0.009 \%$ and $0.006 \%$, respectively. The imbalance between concentration and development of disciplines still exists.

The lack of professional setup, convergence and concentration of disciplines lead to the lack of match between the professional structure and the industrial structure, which makes it difficult to effectively solve the problem of lack of professional talents or oversupply.

3.2 The matching degree of talent training quality and industrial development needs urgently Colleges and universities are the main positions of the training of applied talents. The high or low quality of colleges and universities directly determines whether colleges can provide high-quality applied talents for the development of social economy and industrial transformation and upgrading. However, the quality of the training of applied talents depends on many factors, the number of teachers with double teachers is limited, the time of professional setting is insufficient, and the professional hardware conditions are not strong, which causes the quality of the training of Applied Talents in Colleges and universities to be improved urgently. The structure of knowledge and ability of students can meet the social and economic development and the industrial transformation. There is a certain gap between the upgrading needs and other aspects. The matching quality of applied talents training and Shandong industrial transformation and upgrading needs not very high.

\section{Conclusions}

At present, the economic field of Shandong has entered the deepening stage of the structural reform of the supply side, and undoubtedly puts forward new and higher requirements for the training of talents in Colleges and universities, especially for the training of applied talents. Colleges and universities must meet and meet the demand for applied talents for the reform of the economic supply side, and only from the training and supply side of the talents. With the corresponding reform, we can effectively play the functions of universities and make themselves develop. Therefore, this study aims at combing the meaning of the supply side structural reform and the training of applied talents, excavating the existing problems of the training of Applied Talents in Shandong colleges and universities in the view of the structural reform of the supply side, and laying the foundation for the reform of the training of Applied Talents in the universities of Shandong.

\section{Fund Project}

Shandong social science planning research project:Research on the training of Applied Talents in Shandong colleges and universities from the perspective of supply side structural reform (18CJYJ28). Supported by scientific research team of Shandong Xiehe University.

\section{References}

[1] Kong Fanmin. The way to build applied universities. [M]. Beijing: Peking University press, 2006.

[2] Chen Yong Xian, Su Zhilan, Sheng Zhengfa. Based on the concept of supply side structural reform, the research of talent training in local undergraduate universities [J]. contemporary education forum, 2017,01.

[3] Cao Yuping.How to reform the supply side reform of applied universities? [N].Guangming Daily, 2016,06,22.

[4] Bie Dunrong, Qi Tianyu.Foreign first-class university undergraduate teaching reform and construction trend of [J]. China higher education research, 2016,07. 
[5] Wang Fang.Based on the supply side reform, the training of Applied Talents in Colleges and universities [J]. Jiangsu higher education, 2016,05. 